\title{
Pathos and Its Implication in the Philokalia Fathers
}

Hendi' ${ }^{1}$, Deswita Jihole ${ }^{2}$

1,2Prodi Teologi, Sekolah Tinggi Teologi Soteria Purwokerto

1hendi@sttsoteria.ac.id, ${ }^{2}$ deswitajihole@gmail.com

\begin{tabular}{|c|c|}
\hline Article History & Abstract: This article is a review of $\pi \dot{\alpha} \theta o \varsigma$ (pathos; lust; desire) according to \\
\hline $\begin{array}{l}\text { Submitted: } \\
\text { June, } 19,2020 \\
\text { Revised: } \\
\text { February, } 13,2021 \\
\text { Accepted: } \\
\text { March, } 03,2021\end{array}$ & $\begin{array}{l}\text { the Philokalia fathers. Pathos is the irrational expression of the soul. It arises } \\
\text { from human decisions and choices (free will) alienated from Christ and } \\
\text { becomes the disease of the soul (heart). This paper examines pathos, a list of } \\
\text { pathos, the pathos process, and how to heal the pathos. The method of the study } \\
\text { is the literature review by analyzing the Philokalia texts and other resources. }\end{array}$ \\
\hline $\begin{array}{l}\text { Keywords: } \\
\text { ascesis; } \\
\text { desire; } \\
\text { pathos; } \\
\text { Philokalia; } \\
\text { nepsis }\end{array}$ & $\begin{array}{l}\text { Philokalia is a set of spiritual writings of the Church Fathers based on the } \\
\text { Orthodox spiritual tradition. Pathos can only be healed by spiritual practice or } \\
\text { discipline (ascesis). Each pathos requires a different ascesis. Jesus Prayer, } \\
\text { nepsis, and prayer of the heart are the primary therapies for the sickness of the } \\
\text { soul (pathos). The therapy is the purification of the soul to achieve theosis } \\
\text { (becoming the likeness of Christ). }\end{array}$ \\
\hline $\begin{array}{l}\text { DOl: https://doi.org/ } \\
\text { 10.30995/kur.v7i1.195 }\end{array}$ & \\
\hline
\end{tabular}

\section{Introduction}

This is a review article of pathos $(\pi \alpha \dot{\theta} \theta \zeta)$. Pathos is the desire or sickness of the soul. The Philokalia fathers have elaborated the long explanation of pathos. Philokalia is a set of spiritual writings of the church fathers based on the Orthodox or Eastern tradition since fourth until fifteen centuries. Anthony M. Coniaris defines that Philokalia as the only book that contains a collection of spiritual teachings that can lead the our life to the true and holy path in glory and union with God. ${ }^{1}$ One of the teachings discussed in Philokalia is pathos. Christopher C. H. Cook, in his article, emphasizes that Philokalia is a book that has a profound impact on the lives of believers because it can lead a person to renew himself more. Renewing heart by removing lust or evil desires is the spiritual stage to reach the stage of purification (theosis). ${ }^{2}$

However, most Christians today do not know pathos comprehensively in the view of fathers. At the same time, God has bestowed on someone free will to maintain his pathos according to the law of God. As a result, some desires produce good deeds and vice versa depending on free will. Hendi wrote that pathos is a hostile to human beings because our free will is controlled by wrong thoughts (logismoi) incompatible with God's law. Pathos arises as

\footnotetext{
${ }^{1}$ Anthony M. Coniaris, Philokalia: The Bible of Orthodox Spirituality (Minneapolis: Light \& Life Publishing Company, 1998).

${ }^{2}$ Les Lancaster, "The Philokalia and the Inner Life: On Passions and Prayer, by Christopher C.H. Cook," Mental Health, Religion \& Culture 16, no. 1 (2013): 119-120.
} 
a result of human decisions and choices alienated from Christ. ${ }^{3}$ Pathos becomes a disease of the soul because it is directed against the law of God. But not many of us take priority to spiritual health to cure the pathos. They think physical health is more important than things related to the soul. Though both are equally important. Hendi emphasizes that the life of spirituality is very influential in the life of a believer because the life does not only prioritize physical health but should be balanced with mental health (spiritual) so that the Holy Spirit control the life including desires which are directed according to God's will. ${ }^{4}$

The Philokalia fathers pay attention to the health of their souls because they believe that when the soul does not care, it will be attacked by various diseases. They were not directing themselves to all kinds of desires but becoming new beings in Christ who are constantly renewed so that they glorified God. When pathos is wrongly directed to evil things, it will passively shackle the soul. The fathers say that pathos is one of the enemies who attack and enslave the soul because it is the seed of lust which is an impulse from the subconscious and quickly becomes obsessive.

Five fathers will be defined: Evagrius of Pontus, John Cassian, John of Damascus, Peter of Damascus, and Gregory of Sinai. Eight forms of pathos will be described in detail: gluttony, unchastity, avarice, anger, sadness, listlessness, vainglory, and pride. When these eight pathos have taken control of the human soul, what was previously considered as something that is not being perceptive pathos becomes percussion. The pathos that was given by God to glorify Him now is made into sin. When these pathos are embedded in a person's mind (nous), the process begins immediately. A person's mind will be instigated by Satan, and when someone is attracted, the pathos will become mental images (logismoi) and the images will continue to be the desires of the flesh (pathos) which could only be cured by spiritual disciplines like Jesus Prayer, reading the Scriptures, hesychia, nepsis, fear of God, and repentance. Both the senses and the soul must be synergized with Jesus Christ. Alfius Areng Mutlak said that the spiritual disciplines are those personal and corporate disciplines that promote spiritual growth. They are the habits of devotion and experiential Christianity that have been practiced by the people of God since biblical times. ${ }^{5}$ The Spiritual discipline is not temporary but continually to achieve spiritual growth and union with God. Thus, he is enabled to reject pathos and attain the power of divine energy is called a gift, mercy, and grace. ${ }^{6}$ We the energy, mercy, gift of Holy Spirit to cure the pathos by attaining continual prayers. However, prayer, fasting, vigil and all the other Christian practices may be, they do not constitute the aim of our Christian life. Although it is true that they serve as the indispensable means of reaching this end, the true aim of our Christian life consists of the acquisition of the Holy Spirit of God.

\footnotetext{
${ }^{3}$ Chrystopher Charles Holland Cook, "Philokalia and Mental Wellbeing” (Department of Theology \& Religion Durham University, 2010).

${ }^{4}$ Hendi, "Renewing the Nous: Watchfulness and Praying," DUNAMIS: Jurnal Teologi dan Pendidikan Kristiani 4, no. 2 (2020): 276.

${ }^{5}$ Alfius Areng Mutlak, "Disiplin Rohani Sebagai Praktek Ibadah Pribadi," Jurnal Theologia Aletheia 18, no. 10 (2016): 6.

${ }^{6}$ Hendi, "Pertobatan Di Dalam Philokalia: Artikel Ulasan," Dunamis: Jurnal Teologi dan Pendidikan Kristiani 3, no. 1 (2018): 5.
} 


\section{The Method}

This is library research that examines the texts written by the Philokalia fathers and the book of Christopher C. H. Cook, Mental Well Being. The topic is also elaborated with other supporting books as well as several texts in the Scriptures.

\section{Result \& Discussion}

\section{Pathos ( $\boldsymbol{\pi} \boldsymbol{\alpha} \boldsymbol{\theta} \boldsymbol{\alpha} \varsigma$ )}

Pathos is lust or desire, which refers to a passive experience of the soul that is dominated by desires such as anger and jealousy. Pathos is the expression of the irrational part of the soul. According to the Nicomachean Ethics by Aristotle, there are eight desires which are very vulnerable to feelings, emotions, experiences, and affection. ${ }^{7}$ Pathos consists of seven forms. First, gluttony is a habit of greed, especially in terms of overeating. Second, unchastity is sexual desire. Third, avarice means greed for wealth or material gain. Fourth, anger is a feeling of irritation or being hostile to other people. Fifth, sadness is the feeling of depression or low spirits. Sixth, listlessness is a lack of energy or fatigue. Seventh, pride is selfsatisfaction. This seven pathos can lead a person to sin because pathos is an uncontrollable desire from the needs of one's body but can be overcome with proper discipline accompanied by virtues. ${ }^{8}$ Pathos is more accurately defined as the desire that is not controlled so that it can ensnare someone to sin.

Gregory of Nyssa describes pathos as a quality that a person inherits from animal nature. ${ }^{9}$ Humans inherited the traits of animals that had come to the world before humans. Evagrios has a different concept in describing pathos. He uses the concept of desire in his works. He says that pathos is closely related to the mind, eight thoughts are interpreted as pathos according to Evagrius. It is external and internal or desire of the soul and body. ${ }^{10}$ Meanwhile, Maximus the Confessor says that pathos is the impulse of the soul that is opposite to nature. It can motivate for temporary enjoyment with selfishness and not an eternal and divine purpose. ${ }^{11}$ Therefore, pathos is grouped into one definition: emotions, desires, attitudes, and behaviours, and some of these definitions involve a thought process that even goes beyond human thought, which ultimately leads to human life away from God. Pathos deals with the process of tempting evil, responsibility, desires, choices, and experiences of the mind or nous.

\section{The List of Pathos}

There are 298 forms of pathos listed by the Philokalia fathers but only eight of the major forms of pathos generally attack the mind. ${ }^{12}$ They are gluttony, unchastity, avarice, anger, sadness, listlessness, vainglory, and pride. ${ }^{13}$ There are five Philokalia fathers who explain the

${ }^{7}$ Cook, "Philokalia and Mental Wellbeing." 63.

${ }^{8}$ Living the Orthodox Christian Life (South Carolina, Greenville: Saint George Greek Orthodox Cathedral, 2009). 134.

${ }^{9}$ Coniaris, Philokalia: The Bible of Orthodox Spirituality.

${ }^{10}$ Cook, "Philokalia and Mental Wellbeing."

${ }^{11}$ Ibid.

12 Ibid.

${ }^{13}$ Ibid. See the table 2.1 and 3.1, 58, 98. 
eight main forms of this pathos: Evagrius of Pontus, John Cassian, John of Damascus, Peter of Damascus, and Gregory of Sinai.

Evagrius of Pontus. ${ }^{14}$ Gluttony is the mother of hatred. Gluttony is symbolized (allegory) as wood which is helpful for fuel in burning. The greed is wood which means a desire for eating and it is like a burning fire. The result is disobedience, the darkness of mind, obstacles to prayer, dull intelligence, shameful thoughts, and a far from immodest lifestyle.

Unchastity is the act of adultery or impurity, in other words, the devil's impulse, which forces a person to desire bodily pleasure. Evagrius figuratively categorized it as follows. First, the oil lamp, which means meeting a woman whose life is full of happiness (blazing), a ship without an anchor that is constantly being hit by the waves, which means thinking that has crossed the line that always feels of fornication (the form of a woman's body). Second, the wounds caused by poisoned arrows meant the sight of a woman whose body and soul were riddled with injuries. Third, a fertile plant by the water means a meeting with a woman (giving rise to immoral desires). Fourth, a stake erected at the base means fornication. Fifth, a ship caught in a storm that will be anchored in port means solitude. Impurity can result in a person neglecting his life because it is filled with pleasures and desires.

Third, avarice is the root of all evil (I Tim. 6:10), which nurtures lust that remains like evil branches. Evagrius categorizes and provides the following comparisons. First, root means greed, branch represents passion or other passions. Second, a boat full of cargo is likely to cause the boat to leak and quickly sink due to sea storms. The meaning of boat is monks while cargo means treasure and waves are a worry. Greed is always having other pleasures, namely sadness and desires that will not be satisfied because all of his desires are never satisfied, and other desires always arise.

Fourth, anger is a desire that leads to outrageous things, and the effect of anger is to make the believer's soul run wild, and anger can avoid his life with others from all forms of encounters. The allegory is first, water that is moved by the wind means that water is an irritable person and current is an irrational thought. Second, the fog that freezes the air fog is interpreted as a state that can move angry quickly. Third, the air is defined as intelligence, then clouds that darken the sun mean the mind that is always thinking about hatred. Fourth, the angry lion hinges the cage, the lion is likened to the monks, and the cage hinge means angry thoughts are categorized for monks who can have angry thoughts. Fifth, a falling stone destroys the still water, which means the human heart is evil, stone means evil, and water means human heart. Therefore, anger can cause a mental disturbance, intelligence, dark thoughts, separation from God, and hinder every prayer that is offered to God.

Fifth, sadness is mental aberrations based on angry thoughts because anger is the longing for revenge and the frustration of revenge produces sadness. The sadness in Evagrius practices also speak of sorrow arising from frustrated desires. The allegory is first, the lion who devours means the throat/ stomach of a lion, in other words, what sadness is eaten. Second, the worm in the heart is indicated by a nature that is suffering from sorrow. Third, a

\footnotetext{
14 Ibid.
} 
prisoner who is bound and unable to escape means a contemplative. The consequences of grief are suffering, loss of spiritual pleasure, inhibiting prayer, and dulling the mind.

Sixth, listlessness is soul relaxation. However, this soul relaxation is incompatible with nature because it does not mean noble temptation to resist. Evagrius categorizes and gives several metaphors. First, the north wind nourishes young plants; what is meant by the north wind is temptation, and plants are the soul's endurance. Second, clouds without water are driven away, so cloud means mind without perseverance, and the wind is sadness. Third, a gentle breeze bends a weak plant, so a gentle breeze means a dream about a long journey, and a plant means a monk. Fourth, a tree with good roots is not shaken by the wind, and the tree means a strong soul and the current means sadness. Fifth, a sick person is not satisfied with just one kind of food, so a sick person means a monk suffering from sorrow; food means a type of work. Sixth, a man who loves pleasure is not satisfied with his wife. The seven sick people cannot carry heavy burdens, so sick people mean people who suffer from sorrow, and burdens mean God's work. The consequence of lethargy is wandering restlessly because of any service performed for selfish motives, dissatisfaction with work, distraction, and laziness in prayer.

Seventh, vainglory is the irrational desire and easily influenced by virtuous work. The allegory is first, the grass surrounding and entangles a tree so that its roots die; root means virtue. Second, the wind that erases footprints means almsgiving. Third, a ship loses its cargo because it loses its balance due to fighting the underwater currents, namely the rock, which means the load of pride. The consequences of pride are the destruction of virtue, hindering prayer, and making many enemies.

Eighth, pride is a tumor of the soul filled with pus; when it is ripe, it will burst and create a disgusting mess. The allegory is first, a flash of lightning followed by thunder, so lightning means arrogance, and thunder is pride. Second, the grape supports are used to support the young branches, which are full of fruit; the meaning of the vine helps the fear of God, and the weight of the fruit is pride. Third, an infected wound can heal if operated on with a scalpel (surgery) which means disgrace and sadness. The consequences of pride are collapse, terrifying fantasies and attacks from Satan, and interruption of prayer.

John Cassian ${ }^{15}$ also said that there are eight vices. First, gluttony which is the desire to eat excessively. The way to control it is accustomed to fasting and avoiding overeating (diet), besides that self-control over food also needs to be considered not to be deceived by the enjoyment of food. Every food that is put in the stomach will give birth to seed (Eze. 16:49). When a believer consumes food, he must provide it according to what the body needs to satisfy desires and even enslave himself. Still, the health of the body must also be maintained not to keep his body away from holiness. Therefore, stop eating while still feeling hungry and not eat until you are full (Rom. 3:4). Therefore, self-control and fasting are two essential means for achieving mental purity. The believer must take control of the stomach and bring his body into submission or obedience in doing spiritual things such as reading spiritual like Holy Scriptures, focusing on the fear of God, and always longing for the Kingdom of Heaven.

${ }^{15}$ St. Nicodimos \& St. Macarios of Corinth Of Holy Mountain, The Philokalia: The Complete Text, ed. and Kallistos Ware G. E. H. Palmer, Philip Sherrard, Volume 3. (London: Faber and Faber, 1984). 73. 
Second, unchastity is the desire of the flesh which needs to be avoided. Impurity and the lust are desires that will make it difficult in struggling both in the soul and body. Cassian provides a way to combat this desire, namely fasting, repentance through intimate prayer with God, and reading the Scriptures. In this way, the believer can restrain himself from attaining spiritual purity. However, Cassian said that fasting to purify the body and guarding the mind, not only focus on physical matters but also on spiritual things (see Matt. 23:26). To reach the stage of refinement, believers cannot rely on their strength but through the grace by continuing to maintain holiness in fearing of Him.

Third, anger is a poison that can kill the heart's eyes, which is the depth of the soul of the believer. Anger can cause the believer not to see the truth because when it happens the believer has opened the door for Satan to enter and control his soul. When Satan has mastered the anger of the believer and his mind is dark and far from light, his soul will become a slave to anger and hatred. Therefore, to release anger from within, it is necessary for asking the grace of God and the guidance of the Holy Spirit to be accompanied by repentance.

Fourth, sadness is a soul that experiences sorrow where the soul can contemplate and maintain spiritual actions properly. The believer must guard his heart against grief to not be filled with bitterness, hatred, and resentment. To let go of this resentment, what you should do is pray, meditate on the Scriptures and live together with people who fear God.

Fifth, listlessness is a disease that can make the believer's soul not enthusiastic in doing everything. Listlessness can be a waste of time. To get rid of this listlessness is to meditate on the Scriptures and stay away from temptation and increase the patience.

Sixth, vainglory is a person's excessive arrogance towards oneself because it stands out more than others. The way to get rid of this attribute is by humility, prayer, and fear of God.

Seventh, self-esteem is a passion that anyone quickly feels. Self-esteem is also a tricky thing to fight because it can be identified by sharing ways like speaking, reading, praying, working, and silence. Self-esteem is often seen when believers often pride themselves in front of others. The way to get rid of this attribute is to refuse every compliment that comes into the mind that boasts before God; then He will be freed by this quality that can attract and bind.

Eighth, pride is the evilest trait among other characteristics because this trait can attack anyone, even someone who has reached the level of holiness. Pride can destroy the soul because it can kill all members of the body; pride can darken anyone's soul because someone proud will fall into arrogance. Pride results in believers unable to achieve perfection in holiness because to achieve holiness requires humility and fear of God and has a mild nature.

John of Damascus ${ }^{16}$ said that there are eight desires: gluttony, unchastity, avarice, anger, dejection, listlessness, self-esteem, and pride. The pleasure of craving takes many forms because one will seek satisfaction that is centered on impurity and bodily pleasures, and other desires. To cure this pathos is to think about impurity and abandon all other forms of desires. Since when a person has been bound and lived in pleasures such as greed, he will be immoral and destroy his life. Humans prefer the satisfaction of the body; therefore, it is not surprising that someone whose life is tangled by greed will continue to focus on material

${ }^{16}$ St. Nicodimos Of Holy Mountain \& St. Macarios of Corinth, The Philokalia: The Complete Text, ed. and Kallistos Ware G. E. H. Palmer, Philip Sherrard, Volume 2. (London: Faber and Faber, 1983). 337 
things only. Such desires are contrary to nature because their desires based on their own choice. Therefore, the desire for pleasure is centered on physical desire not spiritual. Intelligent of the soul is mistrust, hatred, and jealousy. It can be healed by steadfast faith in a loving God, the teachings of the Apostles, and prayer through the Holy Spirit's guidance. The aspects of sins can be healed through fasting, self-control, loving, and helping people who are poor and have a heart that always longs for God. The exact cause and effect of the pathos forms start from the word provocation, which is a picture that is encountered from the image that is processed to the amalgamation and continues until the agreement, namely the surrender of the soul to pathos which is likely to produce thoughts can generate pathos itself.

Peter of Damascus ${ }^{17}$ also mentioned eight pathos: gluttony, unchastity, avarice, anger, sadness, listlessness, self-esteem, and pride. Man has lived according to his own will, controlled by evil thoughts. What the believer has to do is to obey and do His commandments through virtues. He said that knowledge of the light that comes from the sun, when a person slowly opens his eyes and ignores the morning, he fails to see the light and does not know to practice how that light comes. Ignorance leads to laziness. Forgetfulness breeds self-love, which is love for one's desires and thoughts, such as pleasure in praise. Self-love comes greed, and greed is the root of all evil (I Tim. 6:10); thus, the world is filled with the desire of the world, no longer knows the gifts of God. Anyone who has the pathos will experience total despair and destruction in his life because he is far from God. After all, man has chosen his path. But he can return to the direction of God unless he chooses the right way and surrenders his life in God's grace and not in the hands of Satan.

Gregory of Sinai also states eight pathos. ${ }^{18}$ He said that virtue has a close union with the soul in body and spirit. Virtue can express a believer's inner purity and holiness. Gregory explained the position of the eight desires that rule humans. First, gluttony and self-love are the two desires that lead humans. Then, there are the six main pathos: impurity, anger, avarice, self-esteem, vainglory, and pride. And the six pathos could be cured by doing the virtues: self-control, humility, purity, gentleness, joy, courage, and not looking down on others. Gregory emphasized that anger as an absurd and mindless desire arising from bodily fluids, which is an impulse of soul force followed by soul desire. Each of these impulses can produce courage and love that is divine. The way to deal with the other six pathos is having the attitudes of heart. The humbleness of the soul in silence and faith are the correct attitudes of heart. Because when it is neglected, one of the six pathos will continue to bind and destroy faith and even destroy the soul.

\section{The Process of Pathos}

Evagrius of Pontus said that the process of pathos begins with three pathos. First, greed for food or gluttony causes the believer's mind to become greedy, and Satan will instigate other pathos such as anger, suffering, pride, and desire. ${ }^{19}$ The Philokalia fathers maintain the

${ }^{17}$ Nicodimos \& St. Macarios of Corinth St. Of Holy Mountain, The Philokalia: The Complete Text, ed. and Kallistos Ware G. E. H. Palmer, Philip Sherrard, Volume 3. (London: Faber and Faber, 1984).

${ }^{18}$ St. Nicodimos Of Holy Mountain \& St. Macarios of Corinth, The Philokalia: The Complete Text, ed. and Kallistos Ware G. E. H. Palmer, Philip Sherrard, Volume 4. (London: Faber \& Faber, 1995).

${ }^{19}$ St. Nicodimos Of Holy Mountain \& St. Macarios of Corinth, The Philokalia: The Complete Text, Faber \& Faber, Volume 1. (London: Faber and Faber, 1979). 38 
tension necessary to recognize both external influences and inner motivations. Pathos is the second aspect of the human psyche, but also something external to influence. They are thus the focus of the internal struggle against the enemy who threatens to destroy and enslave. However, pathos is hostile not only to evil but also to pleasure, and it is a dynamic process that invites comparison with the addiction phenomenon and provides fun and pain. They attract and enslave; they seduce and destroy. Second, pathos offers a framework for the exploration of spirituality and prayer. If the pleasure that draws humans only enslaves the human being. ${ }^{20}$

Evagrius explains the pathos process of these eight main pathoses by quoting an explanation from the Mark of Ascetic and is not sure whether Mark adopted this explanation or not. He said that the Pathos process starts from provocation, which results in momentary disturbances and intellectual intelligence, and will be driven into pleasure that ultimately the believer's mind is instigated and will give consent. ${ }^{21}$ When that happens, he must fight these desires and free himself from every sin of the mind by praying and obeying every rebuke given. When his mind or knowledge succeeds in rejecting these desires, Allah will bring back the previously filled sense with the darkness of sin. But if he refuses, then what happens is the opposite.

Second, according to John Cassian, the pathos process inferred the meaning of pathos through allegory and metaphor. ${ }^{22}$ The pathos process happens when Satan has controlled the eight pathos in the mind. To deal with the pathos process requires self-control and not to be deceived by Satan's incitement. This eight pathos although only one pathos has succeeded in inciting the believer, then gradually the process will continue until the eight pathos also instigates and control it. Therefore, the believers must always prevent the eight pathos process from entering and managing his mind, namely by focusing his heart full of fearing of God and persevering in prayer full of regret, reading the Scriptures, and holding back and mastering the soul of each. The temptation and desire that can come at any time to flirt. In this way, the body, soul, and mind will experience and achieve the purification.

Third, the pathos process, according to John of Damascus, ${ }^{23}$ begins with provocation. He said that the pathos process occurs when a believer's mind receives a whisper/suggestion from Satan; when that happens, his mind will think about the story and deliberately end the tale in a way according to his pleasure. He allowed the imagination of the whisper to stick to the mind continuously. The lust of the flesh and the spirit are wrestling each other like John of Damascus quotes in Gal. 5:17. That is the resistance offered to a fiery mind; the effect is destroying the mind or nous. And this process continues with the body's desires because he also receives approval for this pathos embedded in his mind. And the effect is that his free will forcefully encourage and control the heart to return to old habits.

${ }^{20}$ Cook, "Philokalia and Mental Wellbeing."

${ }^{21}$ Ibid. see the table 3.4a. 107, 108 \& Mark of Ascetik, The Philokalia: The Complete Text Volume 1, 1, 140, 153, 145, 119, 122, 138. Volume 1

22 St. Nicodimos Of Holy Mountain \& St. Macarios of Corinth, The Philokalia: The Complete Text

${ }^{23}$ Cook, "Philokalia and Mental Wellbeing." See the table .4d. 111 \& John of Damascus, The Philokalia: The Complete Text Volume 2, 337. 
Fourth, the pathos process defined by Peter of Damascus ${ }^{24}$ is the understanding of good and evil. He said that a person's soul would experience a disturbance where his mind will choose whether to agree or not because a person's soul will experience a reaction when confronted with that thought. According to God's will, it is praiseworthy, but if it is according to evil, it needs to be investigated. Then one's intellect will struggle with the mind both to conquer and to be conquered, and this pathos process will bring intelligence to both reward and punishment; this happens when thoughts are manifested in action. Peter said that pathos occurs when a fiery mind and soul are united for a long time to produce passion. What happens is the reason will force the soul and make pathos action, and as a result of this action, repentance is highly demanded, but when ignored, it must undergo punishment in the age to come.

Fifth, Gregory of Sinai ${ }^{25}$ said that the process of pathos consists of seven terms: provocation, compounding, wrestling, passion, agreement, actualization, and captivity. Gregory said that the source of evil originated from Adam's disobedience. The memory of his soul which was previously created by God has now been destroyed by the satisfaction of his natural desires. Therefore, restoring memory utilizing increasing his relationship with God through prayer. The pathos process, according to Evagrius, starts from sinful actions that provoke pathos and provoke disturbing thoughts. The thoughts will generate fantasies or delusions. The process continues, namely memories, fragmented memories or actions will generate many ideas, then forgetfulness causes fragmentation of memories. Ignorance leads to forgetfulness and lazines. Laziness is grown by the pathos of lust; misguided emotions and misdirected emotions generate the pathos of eating by committing sinful actions. Sinful acts are provoked by the unthinkable desire for evil and strong attachment to the senses and sense of things.

Disturbing thoughts arise and are controlled by the intellectual ability of the soul. Gregory said that evil thoughts disturbance like river. One's mind is disturbed and finally provoked to sin. Therefore, he gives permission to sin because his heart has been overwhelmed by turbulent spirit. The pathos committing sin in fantasy is now changed and transformed into reality. These opportunities can produce thoughts that can distract attention, then daydream or fantasize on each pathos. Finally, these pathos give access to Satan because of passion. More precedes the devil and the devil follows the pathos. Gregory also said that the deadly poison of the sting of sin is the state of a person's soul filled with passions. Passion consists of two parts. First is love, greed, dissatisfaction, self-pleasure, greed, and self-love. The second is the passion of the flesh like impurity, adultery, uncleanness, waste, injustice, covetousness, lethargy, pride, adornment, cowardice. That is why Gregory said that to avoid this pathos extra strength is needed.

Pathos exists in all human beings, including believers, depending on how the pathos is directed toward sin or virtue. Evagrius said that provocation, which results in momentary distraction and intellectual intelligence, will be pushed into pleasure, and ultimately the mind

${ }^{24}$ Ibid. See the table 3.4b. 108 \& Peter of Damascus, The Philokalia: The Complete Text Volume 3, 207.

${ }^{25}$ Ibid. see the table 3.4f. 113-114 \& Gregory of Sinai, The Philokalia: The Complete Text Volume 4, $223,225$. 
of someone who has been incited will give consent. So, the pathos that Satan has controlled is not instantaneous in directing the human mind to sin, but He begins by prompting the reason with all kinds of means that will be used to force the mind and follow the process. Then all knowledge will enter into the process of sedition. After that, the believer's mind is given pleasure to the level of comfort. When the reason has gotten deeper into the trap of pathos, it automatically approves Satan. So that with the various media used by the devil (pictures), his mind will be easy to control. When that happens, a person must fight those desires and free himself from every sin of the mind by praying non-stop and obeying every command of God. When a person's mind or knowledge succeeds in rejecting these desires, God will return his mind, which was previously filled with the darkness of sin. Still, if he refuses, the opposite will happen and will further destroy his life because it is no longer Christ who controls his mind but Satan.

\section{The Therapy of Pathos}

To cure the pathos, the Philokalia fathers emphasized a practical life, a lifestyle that enhances spirituality or ascetic life, which includes hesychasm or silence, nepsis, Jesus Prayer, reading the Scriptures, repentance, and self-control. Even though in practice this kind of lifestyle, various kinds of spiritual battles will be faced, but behind it some results are obtained, namely being renewed and restored from pathos. Because the healing of the eight pathos is not instant, but there is a process that must be passed.

The Philokalia fathers emphasized a lifestyle of silence so that believers could fight against various pathos despite inner warfare. ${ }^{26}$ Therefore, ascetic life or spiritual discipline is necessary and must be made as a lifestyle to find inner silence. When this is practiced continuously, the eight pathos will be healed day by day. Evagrius proposed the right method to restore someone who is bound by pathos is to make the Lord Jesus Christ a soul healer who can heal all kinds of pathos, which are mental illnesses by practicing spiritual life, one of which is ascetic (see Mat. 9:12, Mark 2:17, Luk 5:31).

Peter of Damascus stated that ascetic life is fundamental to acquiring the virtues that can heal pathos. ${ }^{27}$ Evagrius said that the movement of the five senses naturally regulates pathos, and the workings of pathos include four stages, namely the heart, face, speech (controlling the tongue), and evil deeds, the way to overcome this is by not responding to pathos attacks that attack suddenly because pathos is naturally governed by the movement of the five senses. Evagrius also identifies the practical remedy for these eight desires. ${ }^{28}$ First, gluttony or greed, the way to recover is by fasting and avoiding excessive food consumption and excessive satiety. Second, fornication or impurity can be restored by avoiding thinking about adultery through encounters with women / of the opposite sex, then avoiding arrogant thoughts. Third, avarice or greed, the way to restore this is by freeing the mind from possessing everything, avoiding thinking about property, and being diligent in doing good or charity. Fourth the anger; the way to recover it is to prevent hatred, irritable thoughts, and

\footnotetext{
26 Ibid.

${ }^{27}$ St. Nicodimos Of Holy Mountain \& St. Macarios of Corinth, The Philokalia: The Complete Text.

${ }^{28}$ Cook, "Philokalia and Mental Wellbeing."
} Volume 3, 103-104. 
nature that always provokes others. Instead, it replaces anger with compassion and gentleness, kindness, withstands the temptations of Satan. Fifth, listlessness is the way to restore it to avoid worldly pleasures, patient, do positive things. Sixth, sadness, the way to recover it is to avoid disturbing activities and thoughts, do not drag on in sorrow, always pray, fill the action with work, cry tears of regret for sins. Seventh, vainglory, the way to restore it is by praying privately to refresh and purify the mind to fight against lust. Eighth, pride, the way to restore it is to avoid excessive self-confidence/strength but always praise and glorify the name of God.

The essence of the medicine recommended by Evagrios. He suggests to live the ascetic or bodily training lifestyle of prayer and psalm. They are the medicines for dealing with this eight pathos. Prayer is not just a cure for lust but the life goal of the believer so that he can know all kinds of sinfulness within him. Besides, Peter of Damascus and Gregory of Sinai added that there are seven main spiritual disciplines to work on: silence and fasting, selfcontrol, prayer, humility, and patience. ${ }^{29}$ Before that stage, other stages must be practiced, namely experiencing repentance and confessing all wrongs before God through prayer and then completed by collaborating this ascetic life with God's Grace because He is the controller of life. When a believer cooperates with Allah in treating pathos, he will be guided by His Grace to become an object of healing for others and progress further in the growth of spirituality for himself and others.

By practicing spiritual discipline: humility, self-control, fasting, fighting the lusts of the flesh, being vigilant, praying in silence, and inviting Jesus to be present in the heart, the believer is enabled to crucify the flesh and all its desires full of evil desires, so that his mind is constantly renewed to be pure and holy. Therefore, spiritual life is significant in healing pathos because pathos is a mental illness that must be healed. The body does not experience defects and is worthy of attaining personal fellowship with God. ${ }^{30}$ However, this spiritual discipline is not a benchmark that can save believers but respond to God's love. It is a spiritual discipline that must be harmonized with constantly asking for God's mercy because of His love that believers are saved. In this way, believers can kill all kinds of flesh and continue to cultivate their spirituality. It is healing through spiritual discipline or bodily training recommended by the Philokalia Fathers.

\section{Conclusion}

The process of pathos can produce two things: first, it can be experienced by everyone and can cause the mind, heart, and even oneself to be far apart from matters of spirituality because sin is a poison that can kill the soul. Second, everyone can enjoy the excellent result of attaining the purity and spiritual growth of pathos when He responds and directs his mind only to Christ. Therefore, it must be opposed. So that the hearts and minds of believers are not bound by this eight evil pathos but are filled by the person of Jesus Christ. Thus, the life of the believer is increasingly being renewed, purified, and restored through spiritual life

${ }^{29}$ St. Nicodimos Of Holy Mountain \& St. Macarios of Corinth, The Philokalia: The Complete Text. Volume 4, 4, 99, 102, 233, 234.

${ }^{30}$ Ibid. 
(fighting the lusts of the flesh, being vigilant, praying in silence and inviting Jesus and making Him a healer of souls in the heart of hesychia, Jesus Prayer, humility, ascesis, control. Self, fasting, reading the Scriptures, Jesus' prayer, repentance, nepsis). Therefore, by Jesus Prayer, the eight pathos will be healed. By doing all of this, a person will receive the result, namely experiencing the weariness of evil things and experiencing and practicing God's love in his life and to others. Believers' lives are constantly being restored and blessed with God's grace. Thus, believers unite (theosis) with God through spiritual growth centered on the person of Jesus Christ.

\section{References}

Coniaris, Anthony M. Philokalia: The Bible of Orthodox Spirituality. Minneapolis: Light \& Life Publishing Company, 1998.

Cook, Chrystopher Charles Holland. "Philokalia and Mental Wellbeing." Department of Theology \& Religion Durham University, 2010.

Hendi. "Pertobatan Di Dalam Philokalia: Artikel Ulasan.” Dunamis: Jurnal Teologi dan Pendidikan Kristiani 3, no. 1 (2018): 5. .

_. "Renewing the Nous: Watchfulness and Praying." DUNAMIS: Jurnal Teologi dan Pendidikan Kristiani 4, no. 2 (2020): 276.

Lancaster, Les. "The Philokalia and the Inner Life: On Passions and Prayer, by Christopher C.H. Cook." Mental Health, Religion \& Culture 16, no. 1 (2013): 119-120.

Mutlak, Alfius Areng. "Disiplin Rohani Sebagai Praktek Ibadah Pribadi." Jurnal Theologia Aletheia 18, no. 10 (2016): 6.

St. Of Holy Mountain, Nicodimos \& St. Macarios of Corinth. The Philokalia: The Complete Text. Edited by and Kallistos Ware G. E. H. Palmer, Philip Sherrard. Volume 3. London: Faber and Faber, 1984.

Of Holy Mountain, St. Nicodimos \& St. Macarios of Corinth. The Philokalia: The Complete Text. Faber \& Faber. Volume 1. London: Faber and Faber, 1979.

- The Philokalia: The Complete Text. Edited by and Kallistos Ware G. E. H. Palmer, Philip Sherrard. Volume 2. London: Faber and Faber, 1983.

- The Philokalia: The Complete Text. Edited by and Kallistos Ware G. E. H. Palmer, Philip Sherrard. Volume 3. London: Faber and Faber, 1984.

- The Philokalia: The Complete Text. Edited by and Kallistos Ware G. E. H. Palmer, Philip Sherrard. Faber \& Faber. Volume 4. London, 1995.

Vlachos, Hierotheos S. Orthodox Psychotherapy (The Science of the Fathers). Levadia, Greece: Birth of the Theotokos Monastery, 1994.

Living the Orthodox Christian Life. South Carolina, Greenville: Saint George Greek Orthodox Cathedral, 2009. 